\title{
TRAINING CAPACITY OF TEACHERS IN RESPONSE TO REQUIREMENTS FOR INNOVATION IN SCHOOL EDUCATION OF VIETNAM
}

\author{
NGUYEN THITINH ${ }^{1}$, NGUYEN THIUT SAU ${ }^{2}$, HA THI KIM LINH ${ }^{3}$, HUYNH TAN HOI $^{4} \&$ KIEUTHI \\ THU CHUNG ${ }^{5}$ \\ ${ }^{1,2,3}$ University of Education - Thai Nguyen University, Vietnam \\ ${ }^{4,5}$ FPT University, Vietnam
}

\begin{abstract}
The requirement to build and develop the country in the context of integration and globalization has set new requirements, with greater responsibility for the school teachers. Among the limitations of the current teaching staff, the most noticeable are the limitations of professional knowledge and the ability to improve self-improvement. The knowledge equipped while stilla student in the university is just basic knowledge compared to the immense sea of knowledge. Currently, the teachers in high schools are mainly those who have graduated for many years, so they do not timely update new knowledge and new methods to meet the requirements of the curriculum and textbooks. The method of teaching most of teachers is oral presentation, recorded by teachers and students. The ability to use informatics to prepare and teach lessons with electronic lesson plans is still limited, especially in remote areas, the self-improvement of teachers' skills is a big challenge for teachers. The capacity of pedagogical teachers is a decisive factor in the quality of training and retraining of general teachers; general education curriculum changes; the changing standard of teacher education requires teachers to be fostered according to a common core curriculum and school curriculum.

KEYWORDS: Capacity, Challenges, Pedagogical Skills, Teachers, Students
\end{abstract}

Received: Jun 08, 2020; Accepted: Jun 28, 2020; Published: Aug 18, 2020; Paper Id.: IJMPERDJUN2020787

\section{INTRODUCTION}

Pedagogical teachers are lecturers at higher education institutions engaged in training and retraining of general teachers. Pedagogical teachers are an important factor determining the quality of training and retraining of general teachers, greatly affecting the quality of the national education system. Capacity building for pedagogical teachers with the purpose of assisting teachers in carrying out training and retraining teachers for career development regularly, meeting the constantly changing requirements of the career and the development of general education and the development of the country.

\section{CONTENT}

With the function of a lecturer, a pedagogical lecturer in addition to training, scientific research, community development, pedagogical teachers are responsible for participating in professional development programs for teachers. Universal tablets (1]. This is one of the requirements and mandates of the lecturers, requiring the teacher training institution to have a plan, organizing training and lecturers to make self-training efforts for continuous professional development (2).

According to Circular 20, 2018 of the Ministry of Education and Training, secondary school teachers need to meet the following 5 professional standards: teacher qualifications; professional development; building an 
educational environment; developing relationships between school, family and society; using foreign languages or ethnic languages, applying information technology, exploiting and using technological equipment in teaching and education (3). Therefore, the issue of fostering teachers' capacity to meet the new requirements for training and fostering teachers according to new professional standards is a necessary work today.

On the other hand, in December 2018, the Ministry of Education and Training of Vietnam issued Circular 32, the general education program, the new subject program and implemented from 2020 to 2021. new tasks for teacher training and pedagogical teacher capacity building to meet the requirements of renewing the general education curriculum. In this context, the development of pedagogical teachers to meet the requirements of reforming general education is both a goal and a motivation and is considered one of the important factors to successfully implement the changing career. new basic, comprehensive education and training in Vietnam.

The above context provides pedagogical teachers with new opportunities and challenges, in terms of integration, open exchanges, innovative thinking, methods and mechanisms for higher education management in the direction of autonomy, self-responsibility (4). The Ministry of Education and Training of Vietnam has issued Circular No. 20/2013 / TT-BGDĐT of the Ministry of Education and Training on promulgating regulations on professional training for lecturers of higher education institutions. Issued on June 6, 2013, the purpose of training is the first mission. Supplementing and updating new professional knowledge according to specialty and training level; requirements of school year duties and requirements to improve the quality of education. Meeting the requirements on professional standards and criteria for lecturers. Improving the capacity of teaching, education, scientific research, organizational and managerial capacity of higher education institutions. Improving ethical qualities, political awareness and professional conscience for lecturers (5).

Next, it is to issue a training program for lecturers according to the standard titles, Decision No. 1611 / QDBGDDT and Decision No. 1612; 1613 Promulgating a training program according to the standards of professional title of lecturers (Class I; Class II and Class III). These training programs are structured in three parts: knowledge of politics, state management and general skills; specialized professional knowledge and skills and professional ethics; learning the facts and write the harvest (6).

The framework of training programs for lecturers according to the standard of profesional titles also includes some contents related to the profesional competence of teachers such as innovating teaching methods and ensuring the quality of higher education. study and build a cultural environment in higher education institutions, International cooperation on education and training. However, these contents are general in nature, common to all lecturers at higher education institutions, and have not seen the specific and specific characteristics of pedagogical teachers (7).

Continuing profesional development for pedagogical teachers who do not have their own programs and the training for pedagogical teachers is done in a small, systematic and unifiedmanner at teacher training establishments (8). Thereality shows that teachers' training schools are based on the actual needs of the teachers, the development orientation of the school and the funds raised, organizing workshops, seminars, and courses. short-term training orsending lecturers to attend short-term training courses at home and abroad. In general, teacher training universities have selected training contents associated with higher education innovation and general education innovation such as STEM education training and cloud classroom technology at Hanoi University of Pedagogy (May 2018), Communication skills in schools, Skills to use IT in teaching at university at Da Nang University of Education (2017), Developing STEM educational activities within the school context, Developing school programs; develop teacher training program in the direction of 
entrepreneurship education; Digital education and online teaching at Thai Nguyen University of Education (2017; 2018; 2019). Training program development; Program evaluation; STEM education; Advice to support students at Ho Chi Minh City University of Education, etc.

To assess the content of training and the level of meeting the training needs of the current training program (pedagogical training program for teachers, training and upgrading program for lecturers' career titles, training content organized by the schools themselves), we have designed the questionnaire on lecturers and managers of 04 key Pedagogical Universities of Vietnam: Pedagogical University - Thai Nguyen University, Hanoi National University of Education, Da Nang University of Education, Ho Chi Minh City University of Pedagogy.

Table 1: Subjects Surveying the Extent of Meeting the Requirements on the Content of Pedagogical Teacher Training Program

\begin{tabular}{|c|c|c|c|c|c|c|c|c|c|c|}
\hline \multirow[t]{2}{*}{ No } & \multirow[t]{2}{*}{ Object type } & \multicolumn{2}{|c|}{$\begin{array}{c}\text { Thai Nguyen } \\
\text { Pedagogical } \\
\text { University }\end{array}$} & \multicolumn{2}{|c|}{$\begin{array}{c}\text { Thai Nguyen } \\
\text { Pedagogical } \\
\text { University }\end{array}$} & \multicolumn{2}{|c|}{$\begin{array}{c}\text { Thai Nguyen } \\
\text { Pedagogical } \\
\text { University }\end{array}$} & \multicolumn{2}{|c|}{$\begin{array}{c}\text { Ho Chi } \\
\text { Minh City } \\
\text { Pedagogical } \\
\text { University }\end{array}$} & \multirow[t]{2}{*}{ Total } \\
\hline & & $\overline{\text { SL }}$ & $\%$ & $\overline{\text { SL }}$ & $\%$ & $\overline{\text { SL }}$ & $\%$ & SL & $\%$ & \\
\hline 1 & Lecturer & 58 & 29 & 46 & 23 & 51 & 25 & 47 & 23 & 202 \\
\hline 2 & Managers & 29 & 53 & 6 & 11 & 10 & 18 & 10 & 18 & 55 \\
\hline
\end{tabular}

Survey results are handled in the following 5 levels:

The average score from 1.0 to 1.8 does not yet meet the requirements for fostering pedagogical teachers. The average score from 1.8 to 2.6 is not fully met the requirements for fostering pedagogical teachers (Table 1). The average score from 2.6 to 3.2 is relatively satisfactory to meet the requirements of training teachers. The average score from 3.2 to 4.2 is at the level that meets the requirements for fostering pedagogical teachers. The average score from 4.2 to 5.0 is very satisfactory for teacher training. The results of evaluating the current training program and the training needs of pedagogical teachers meeting the new professional standards are shown in Table 2 below.

Table 2: Current Situation of the Level of Meeting the Demand for Capacity Building for Pedagogical Teachers in Vietnam

\begin{tabular}{|c|c|c|c|c|c|}
\hline \multirow[t]{2}{*}{ No } & \multirow[t]{2}{*}{ Content of training for teachers } & \multicolumn{2}{|c|}{ 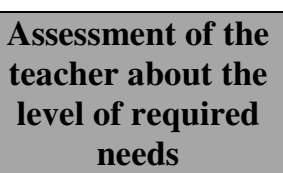 } & \multicolumn{2}{|c|}{$\begin{array}{l}\text { Assessment of the } \\
\text { management officer } \\
\text { on the level of the } \\
\text { required demands }\end{array}$} \\
\hline & & Total & Grade & Total & Grade \\
\hline 1 & Content of training professional capacity & 3.03 & 4 & 2.98 & 4 \\
\hline 1.1 & Specialized knowledge & 3.41 & 2 & 3.69 & 1 \\
\hline 1.2 & The general education program & 3.17 & 4 & 3.07 & 3 \\
\hline 1.3 & $\begin{array}{l}\text { Course program of general education according to the } \\
\text { training sector }\end{array}$ & 3.17 & 4 & 3.03 & 4 \\
\hline 1.4 & Pedagogical fostering for teachers & 3.81 & 1 & 3.69 & 1 \\
\hline 1.5 & Facilitating and upgrading lecturers & 3.34 & 3 & 3.55 & 2 \\
\hline 1.6 & Multicultural education & 2.79 & 7 & 2.34 & 9 \\
\hline 1.7 & Using foreign languages in teaching & 2.64 & 10 & 2.17 & 10 \\
\hline 1.8 & Teaching online & 2.67 & 9 & 2.69 & 8 \\
\hline 1.9 & Integrated teaching & 2.9 & 6 & 2.89 & 5 \\
\hline 1.10 & STEM education & 2.79 & 7 & 2.83 & 6 \\
\hline 1.11 & Differentiation teaching & 2.63 & 11 & 2.79 & 7 \\
\hline 2 & Content of fostering program development capacity & 3.34 & 1 & 3.56 & 1 \\
\hline 2.1 & $\begin{array}{l}\text { Designing a set of stakeholder survey tools to develop } \\
\text { training programs }\end{array}$ & 2.8 & 4 & 3.41 & 5 \\
\hline
\end{tabular}




\begin{tabular}{|c|c|c|c|c|c|}
\hline 2.2 & Developing standard output & 3.42 & 2 & 3.55 & 2 \\
\hline 2.3 & Determining the competency profile for graduates & 3.27 & 5 & 3.55 & 2 \\
\hline 2.4 & Defining knowledge modules and subjects & 3.41 & 3 & 3.52 & 4 \\
\hline 2.5 & Designing the subject outline & 3.78 & 1 & 3.79 & 1 \\
\hline 3 & Content fostering evaluation capacity & 3.14 & 3 & 3.40 & 2 \\
\hline 3.1 & $\begin{array}{l}\text { Developing evaluation standards, design assessment } \\
\text { tools for learning outcomes according to standards }\end{array}$ & 3.24 & 1 & 3.38 & 4 \\
\hline 3.2 & $\begin{array}{l}\text { Making influence and sharing on innovation } \\
\text { assessment activities to colleagues, learners and } \\
\text { teachers }\end{array}$ & 2.99 & 5 & 3.48 & 3 \\
\hline 3.3 & $\begin{array}{l}\text { Mobilizing the participation of learners and colleagues } \\
\text { in the assessment activities }\end{array}$ & 3.24 & 1 & 3.52 & 2 \\
\hline 3.4 & $\begin{array}{l}\text { Adjusting and improving evaluation activities in } \\
\text { teaching }\end{array}$ & 3.24 & 1 & 3.59 & 1 \\
\hline 3.5 & $\begin{array}{l}\text { Adjusting the course curriculum based on the } \\
\text { assessment results }\end{array}$ & 3.01 & 4 & 3.03 & 5 \\
\hline 4 & Content of fostering scientific research capacity & 2.97 & 5 & 2.92 & 5 \\
\hline 4.1 & $\begin{array}{l}\text { Using software in data processing to synthesize } \\
\text { scientific research findings }\end{array}$ & 2.74 & 7 & 3.00 & 4 \\
\hline 4.2 & $\begin{array}{l}\text { Writing scientific papers and international publications } \\
\text { on educational science }\end{array}$ & 2.84 & 5 & 2.66 & 7 \\
\hline 4.3 & $\begin{array}{l}\text { Use of foreign languages in teaching and scientific } \\
\text { research }\end{array}$ & 2.7 & 8 & 2.41 & 8 \\
\hline 4.4 & Application of IT in scientific research & 3.17 & 2 & 3.10 & 3 \\
\hline 4.5 & $\begin{array}{l}\text { Transfer of educational science research results in } \\
\text { education }\end{array}$ & 2.81 & 6 & 2.69 & 6 \\
\hline 4.6 & Cooperation in educational research & 2.91 & 4 & 2.97 & 5 \\
\hline 4.7 & Guiding to do scientific research & 3.45 & 1 & 3.31 & 1 \\
\hline 4.8 & $\begin{array}{l}\text { Compilation of learning materials for training and } \\
\text { retraining of teachers and management officials }\end{array}$ & 3.12 & 3 & 3.28 & 2 \\
\hline 5 & $\begin{array}{c}\text { Contents of fostering a democratic educational } \\
\text { environment, educational consultancy, cooperation } \\
\text { and politics }\end{array}$ & 3.33 & 2 & 3.35 & 3 \\
\hline 5.1 & $\begin{array}{l}\text { Building a democratic educational environment in } \\
\text { higher education institutions }\end{array}$ & 3.24 & 7 & 3.48 & 1 \\
\hline 5.2 & $\begin{array}{l}\text { Consulting, supporting colleagues in professional } \\
\text { development }\end{array}$ & 3.21 & 8 & 3.34 & 6 \\
\hline 5.3 & Building a school culture environment & 3.37 & 4 & 3.34 & 6 \\
\hline 5.4 & Ensuring the quality of higher education & 3.48 & 2 & 3.45 & 2 \\
\hline 5.5 & Consulting and guiding learners & 3.51 & 1 & 3.38 & 3 \\
\hline 5.6 & $\begin{array}{l}\text { Collaborating with secondary schools and other } \\
\text { stakeholders to carry out training activities, train } \\
\text { teachers and conduct scientific research }\end{array}$ & 3.29 & 6 & 3.38 & 3 \\
\hline 5.7 & $\begin{array}{l}\text { Organizing experiential and social activities for } \\
\text { learners }\end{array}$ & 3.31 & 5 & 3.34 & 6 \\
\hline 5.8 & Communication in education & 3.17 & 9 & 3.03 & 9 \\
\hline \multirow[t]{2}{*}{5.9} & Political views & 3.43 & 3 & 3.38 & 3 \\
\hline & GPA & 3.16 & & 3.24 & \\
\hline
\end{tabular}

Looking at the statistical results, it is shown that basically the content of fostering has met the need to foster the capacity of lecturers to meet the needs; none of the content met the demand level very well (Table 2). There are many contents of training to meet the needs of fostering the capacity of lecturers at a level relatively to meet the needs [9].

Content of professional training competence includes multicultural education; using foreign languages in teaching; teaching online; integrated teaching; STEM educational-oriented teaching; teaching differentiation, etc. 
The content of fostering scientific research competencies includes: The capacity to use software in data processing to synthesize educational scientific research results; Writing scientific papers and international publications on educational science; Using foreign languages in teaching and scientific research; Transfer of educational science research results in education; Cooperation in educational research (10).

Survey results on managers and lecturers basically have relatively similar results in two groups of professional competence and scientific research capacity, these are the two basic competencies of lecturers (11). Researching records of management training to improve faculty capacity of the surveyed schools shows that in recent years, schools have focused on fostering program development capacity for lecturers; The capacity to evaluate some contents of online teaching and STEM education has been initially concerned but not yet deep, on the other hand due to financial constraints, so much content on scientific research has not been paid attention. ; On the other hand, the English proficiency of lecturers in schools in the general context is limited, this is also the reason leading to the above situation (12).

\section{CONCLUSIONS AND RECOMMENDATIONS}

Activities of fostering and improving capacity for teachers of Pedagogical University have been implemented, however, they are not synchronous among unique institutions; The level of meeting the needs of fostering the lecturers' capacity is mostly good and average. In order for systematic and effective training of pedagogical training for teachers, the Ministry of Education and Training should issue a framework of core training programs for teachers in all teacher training facilities. Based on this program framework, key pedagogical universities can develop training programs for lecturers suitable to the capacity of each school; Based on the training program, lecturers can select appropriate and necessary subjects for themselves to register for the training course to improve lecturers' capacity in the form of online. On the other hand, schools need to build key teaching staff, promote the development of the learning community of teachers and enhance the role of key teachers in the development of pedagogical career teachers; each pedagogical teacher needs to foster themselves to improve themselves to meet the requirements of training and retraining teachers in the new context.

\section{ETHICAL CLEARANCE}

The authors ensure the quality and integrity of the research. By writing this research paper, the authors all contributed the work together.

\section{ACKNOWLEDGEMENT}

We would like to send our warm thanks to our university as well as the advice from our colleagues in order to complete the paper.

\section{CONFLICT OF INTEREST}

There is no conflict of interest in the paper.

\section{SOURCE OF FUNDING}

The authors would like to send warm thanks to the workplace where they are working for.

\section{REFERENCES}

1. Smith, Kari. So, what about the professional development of teacher educators?. European journal of teacher education, 2003, 26.2: $201-215$. 
2. Dengerink, Jurriën; Lunenberg, Mieke; Kools, Quinta. What and how teacher educators prefer to learn. Journal of education for teaching, 2015, 41.1: 78-96.

3. Van der Klink, Marcel, et al. Professional development of teacher educators: What do they do? Findings from an explorative international study. Professional development in education, 2017, 43.2: 163-178.

4. Duc, Bui Minh, et al. "In the Development of Professional Standards for Vietnamese Teachers: Studies on Singapore's Experience. "International Journal of Educational Science and Research (IJESR) 7. 2, Apr 2017, 149-154

5. Williams, Judy; RITTER, Jason K. Constructing new professional identities through self $\square$ study: From teacher to teacher educator. Professional development in education, 2010, 36.1-2: 77-92.

6. Harman, Kay; Bich, Nguyen Thi Ngoc. Reforming teaching and learning in Vietnam's higher education system. In: Reforming higher education in Vietnam. Springer, Dordrecht, 2010. p. 65-86.

7. Tan, Hoi Huynh. The Applications of Artificial Intelligence and the Abilities of Supporting in Learning Japanese Language. In: Proceedings of the 2019 2nd International Conference on Computational Intelligence and Intelligent Systems. 2019. p. $156-160$.

8. Nguyen, Dongthi Thao, and Kieuthi Thu Chung. "New Trends in Technology Application in Education and Capacities of Universities Lecturers during the Covid-19 Pandemic."International Journal of Mechanical and Production Engineering Research and Development (IJMPERD) 10. 3, Jun 2020, 1709-1714

9. Albion, Peter R., et al. Teachers' professional development for ICT integration: Towards a reciprocal relationship between research and practice. Education and Information Technologies, 2015, 20.4: 655-673.

10. Peeraer, Jef; VanPetegem, Peter. The limits of programmed professional development on integration of information and communication technology in education. Australasian Journal of Educational Technology, 2012, 28.6.

11. Shih-Feng, Tseng. "The Study of the Phenomenon of Fangliao Immigrant Residents' Children Getting Better Academic Performance in Taiwan." International Journal of Educational Science and Research (IJESR) 6.3 (2016).

12. Peeraer, Jef; VAN Petegem, Peter. Information and communication technology in teacher education in Vietnam: from policy to practice. Educational Research for Policy and Practice, 2012, 11.2: 89-103.

13. Lewis, Peter A., et al. Flexible learning: Evaluation of an international distance education programme designed to build the learning and teaching capacity of nurse academics in a developing country. Nurse Education in Practice, 2016, 21: 59-65.

14. Hoi, H. T. Machine Translation And Its Impact In Our Modern Society. (2020). International journal of scientific \& technology research. 2020;9(2), 1918-1921.

15. Chen, J., and Youngsoon Kim. "Heritage Language Education in South Korea and Challenges Faced by Marriage Immigrant Women." International Journal of Educational Science and Research 6.4 (2016): 43-50.

16. Giles, C., \& Hargreaves, A. The sustainability of innovative schools as learning organizations and professional learning communities during standardized reform. Educational administration quarterly. 2006; 42(1): 124-156. 